\title{
Factors Affecting Chemical DTPA-Extractabilily of Some Heavy Metals From Different Soil Types in Egypt
}

\author{
Ragab M.M., A.S. Antar, N.I. Talha and M. I. El-Shahawy ${ }^{1}$
}

\begin{abstract}
The objectives of this study were to determine the amounts of total and available heavy metals in some Egyptian soils and their relation with some soil properties. Five soil profiles; two from Kafr El-Sheikh Governorate located at south Kafr El-Sheikh city and south Baltim city to represent Delta soils and three profiles from El-Beheira Governorate located at Housh-Eisa, Abo El-Matameir and Mariut to represent Delta fringes soils. These profiles were chosen to cover as far as possible the Delta soils (Fluvial and Lacustrine soils) and Delta fringes soils (Sandy calcareous and Alluvial calcareous soils and Calcareous soils) at the northern part of Egypt.
\end{abstract}

Data showed that, the surface layers of Delta soil contained higher amounts of total and available $\mathrm{Cu}, \mathrm{Ni}, \mathrm{Cd}$ and $\mathrm{Pb}$ than the subsurface soil layers and decreased with depth. The contents of total $\mathrm{Cu}, \mathrm{Ni}, \mathrm{Cd}$ and $\mathrm{Pb}$ in Delta soils varied from 246.3 to $102.5,186.3$ to $100.0,9.85$ to 1.85 and 175.0 to $60.0 \mathrm{mg} / \mathrm{kg}$ soil, respectively in the surface layers. The corresponding values of the DTPA-extractable metals were 11.8 to $11.4,0.78$ to $0.8,0.21$ to 0.023 and 0.37 to $0.22 \mathrm{ppm}$, respectively.

The average content of total $\mathrm{Cu}, \mathrm{Ni}, \mathrm{Cd}$ and $\mathrm{Pb}$ for Delta fringes soils varied from one metal to another and also from one soil to another. Therefore, these metals can be arranged according to their contents in the order: $\mathrm{Cu}>$ $\mathrm{Pb}>\mathrm{Ni}>\mathrm{Cd}$. The contents of total $\mathrm{Cu}, \mathrm{Ni}, \mathrm{Cd}$ and $\mathrm{Pb}$ in Delta fringes soils varied from 57.5 to 120.0 , 62.5 to 95.0 , 2.3 to 4.65 and 39.5 to $69.5 \mathrm{mg} / \mathrm{kg}$, respectively for the surface layers. The alluvial calcareous soils recorded the lowest amounts of heavy metals; whereas sandy calcareous soils recorded the highest ones. The available amounts of these metals varied relatively in narrow range and the averages were $2.11,0.16,0.035$ and $0.20 \mathrm{mg} / \mathrm{kg}$ soil for $\mathrm{Cu}$, $\mathrm{Ni}, \mathrm{Cd}$ and $\mathrm{Pb}$, respectively.

The values reveal that metal content is mainly dependent on soil parent material, organic matter content and cation exchange capacity. Highly positive significant correlations were found between clay and silt \% with total and available heavy metals, and also between organic matter content and total and available metals except available $\mathrm{Cu}$. Cation exchange capacity showed highly significant correlations with either total or available metals. On the other hand, negative correlations were found between calcium carbonate and total and available metals. It can be concluded that, the heavy metal contents in the studied soils are affected mainly by the geochemical sources or soil parent material.

\footnotetext{
${ }^{1}$ Soils, Water and Environment Res. Inst., Agric. Res. Center. Egypt Received November 5, 2007, Accepted December25, 2007
}

Keywords. Heavy metals, Delta soils and Delta fringes soils, Total metal, DTPA-metal.

\section{INTRODUCTION}

Heavy metals are the most widely recognized and used term for metals having atomic density greater than $6 \mathrm{gm} / \mathrm{cm}^{3}$ (Alloway, 1995). Also, heavy metals are those elements having densities greater than $5 \mathrm{gm} / \mathrm{cm}^{3}$ (Sparks, 1995). Heavy metals are also classed as "trace elements" because they occur in concentration of less than $1 \%$ in the rock of the earth's crust, Alloway (1995). During the last decade, they have been paid increasing attention owing to their frequent occurrence as soil pollutants. In addition, some of these metals are essential for plant growth, the adequate supply of which is of a great importance in agriculture. The evaluation of potential hazards, when pollution occurs, requires knowledge's of the normal contents of these metals in soils (Rashad, et al. 1995).

The sources of heavy metals are parent material, commercial fertilizers, liming materials, sewage sludge, irrigation with contaminated water, capillary rise of contaminated groundwaters, coal combustion, metal-smelting industries, auto emissions, and others (Sparks, 1995). There are different sources of heavy metals that adversely affect soil properties, especially microbiological activities, plant growth, animal and human health. Hence, they present risk of toxicity depending on their rate of transfer from soil compartments to the soil solution, plants, groundwaters and more generally to the food chain. In Egypt, emission from automobile exhaust, high use of fertilizers and pesticides as well as the industrial activity are the main sources of pollution by heavy metals such as, $\mathrm{Zn}, \mathrm{Pb}, \mathrm{Cd}, \mathrm{Ni}, \mathrm{Mn}$ and $\mathrm{Cu}$ (Shahin and Abdel-Tawab, 1988, Morsy, 1990 and Omran, et al.,1996). Rabie et al. (1989 and 1996) reported that heavy texture, non calcareous and Nile alluvial deposits have the highest micronutrients content, Aeolian sandy soils attain lowest, while calcareous soils display an intermediate case. Highly significant correlation was observed between both total and available micronutrient and clay, clay+ silt, and organic matter content rather than those with mineralogical composition, Rabie et al. (1989), Abou El-Khir (2003) and Dai et al. (2004). Soil pH, Eh, 
exchange capacity, organic matter content, soil texture, oxides content, exchangeable bases and clay mineralogy had great effects on the distribution and uptake of $\mathrm{Mn}, \mathrm{Cu}$, and $\mathrm{Zn}$ and sorption of $\mathrm{Cd}$ in soil (McBride et al., 1981 and McLaren et al. 1983). Heavy metal adsorption varies among soil types and may depend on one or a combination of soil properties (Alloway, 1990). Soil proprieties, often correlated with metal adsorption, include soil pH (Christensen, 1984), soil CEC (Harter, 1979), soil organic matter (Gerriste and Van Driel, 1984) and clay content (Korte et al., 1976.) However, direct cause-and-effect relationships between soil properties and metal adsorption are difficult to determine because soil properties are often intercorrelated. Correlation analysis may inadequately describe these relationships because correlation does not ensure that a direct cause-and-effect relationship exists (Wright, 1921). The current study aimed to determine the total and available heavy metals in some Egyptian soils and their relation to some soil parameters.

\section{MATERIALS AND METHODS}

Five soil profiles, two from Kafr El-Sheikh Governorate located south Kafr El-Sheikh city and south Baltim city to represent Delta soils and three profiles from El-Beheira Governorate located at Housh-Eisa, Abo El-Matameir and Mariut to represent Delta fringes soils. Samples from the different soil layers were collected to represent some soil types in Egypt Fig.1. These locations were chosen to cover as far as possible the following soils types:

\section{1- Delta soils:}

A- Fluvial deposits.

B- Lacustrine deposits.

\section{2- Delta fringes soils:}
C- Sandy calcareous.
D- Alluvial calcareous.
E- Calcareous.

The soil samples were air-dried, gently crushed, passed through a 2-mm sieve. Some chemical and physical properties of the soil samples were determined according to Page (1994). The EC of soil was measured in the soil paste extract by electrical conductivity meter (Model 4320 JENWAY), the $\mathrm{pH}$ was measured in 1: 2.5 soil-water suspension by $\mathrm{pH}$-meter (Model $420 \mathrm{~A}$ ), total $\mathrm{CaCO}_{3}$ by Collins calcimeter and O.M. by Walkly and Black method. The particle size distribution (Sand, Silt and clay) was determined by hydrometer method.

\section{Fig 1. locations of soil samples collected from the Nile Delta and Delta fringes}

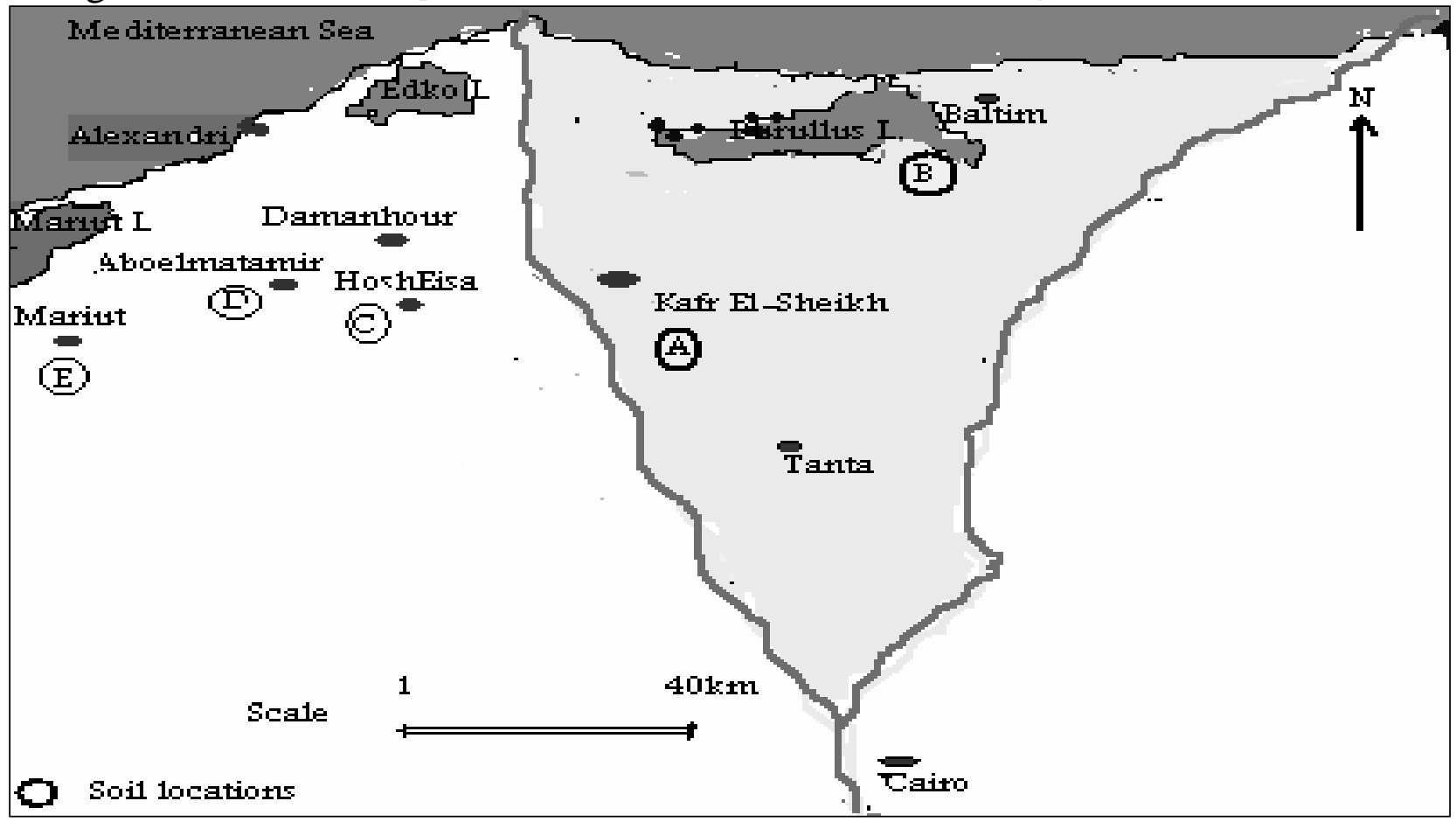


Total content of heavy metals $(\mathrm{Cu}, \mathrm{Ni}, \mathrm{Cd}$ and $\mathrm{Pb})$ in soils were determined using hot extraction with aqua regia (Cottenie et al., 1982).

The available amounts of heavy metals in soil samples were extracted by 0.005 M DTPA solution buffered at pH 7.3 (Lindsay and Norvell, 1978). Both total and available heavy metals were measured by Atomic Absorption Spectrophotometer (Perken Elmer 380).

Statistical analyses were carried out by using computer programs according to Snedecor and Cochran (1967).

\section{RESULTS AND DISCUSSION}

\section{Soil properties:}

Some soil physical and chemical properties of the studied soils profiles are presented in Table1. Data showed that fluvial soils have relatively heavy texture in all layers, where the clay content was found to be around $40 \%$ and the texture class is silty clay.Lacustrine soil is characterized by their heavy texture in the surface (0-30 $\mathrm{cm})$ and subsurface layers $(30-70 \mathrm{~cm})$ where the texture is clay loam and changes with depth $(>70 \mathrm{~cm})$ to light where the texture was found to be sandy clay loam and silty clay loam. Sandy and alluvial calcareous soils are nearly similar particularly with respect to the dominancy of sandy clay loam texture except for top soil layer (0-28 $\mathrm{cm}$ ) in sandy calcareous soils which was loamy

\section{Table1. Chemical and physical properties of the investigated soil profiles}

\begin{tabular}{|c|c|c|c|c|c|c|c|c|c|c|}
\hline \multirow{2}{*}{$\begin{array}{l}\text { Soil } \\
\text { type }\end{array}$} & \multirow{2}{*}{$\begin{array}{c}\text { Soil } \\
\text { depth } \\
\text { (cm) }\end{array}$} & \multicolumn{3}{|c|}{ Particle-size distribution } & \multirow{2}{*}{ Texture class } & \multirow{2}{*}{$\begin{array}{c}\mathrm{CaCO}_{3} \\
\%\end{array}$} & \multirow{2}{*}{$\underset{\%}{\mathrm{OM}}$} & \multirow{2}{*}{$\begin{array}{c}\mathrm{EC} \\
\mathrm{dS} / \mathrm{m}\end{array}$} & \multirow{2}{*}{ pH } & \multirow{2}{*}{$\begin{array}{c}\text { C.E.C. } \\
\text { meq/100 } \\
\text { gm soil }\end{array}$} \\
\hline & & Clay \% & Silt \% & Sand \% & & & & & & \\
\hline \multicolumn{11}{|c|}{ Fluvial soils } \\
\hline \multirow{5}{*}{ A-Fluvial } & $0--30$ & 45.69 & 45.39 & 8.92 & Silt clay & 4.10 & 1.78 & 2.32 & 8.39 & 40.60 \\
\hline & $30--60$ & 48.04 & 44.93 & 7.03 & Silt clay & 2.98 & 1.68 & 3.58 & 8.50 & 48.00 \\
\hline & 60--90 & 47.99 & 44.31 & 7.70 & Silt clay & 3.16 & 0.55 & 7.06 & 8.33 & 42.78 \\
\hline & $90--120$ & 45.25 & 47.72 & 7.03 & Silt clay & 1.22 & 0.63 & 8.47 & 8.14 & 45.67 \\
\hline & $120-150$ & 43.62 & 50.24 & 6.14 & Silt clay & 1.18 & 0.66 & 10.42 & 8.09 & 43.65 \\
\hline \multicolumn{11}{|c|}{ Lacustrine soils } \\
\hline \multirow{3}{*}{$\begin{array}{c}\text { B- } \\
\text { Lacustrine }\end{array}$} & $0--30$ & 36.30 & 40.20 & 23.50 & Clay loam & 14.40 & 2.02 & 84.80 & 7.95 & 33.66 \\
\hline & 30--70 & 36.30 & 24.88 & 38.82 & Clay loam & 15.20 & 2.14 & 64.20 & 7.95 & 26.73 \\
\hline & 70--80 & 21.06 & 13.40 & 65.54 & $\begin{array}{c}\text { Sandy clay } \\
\text { loam }\end{array}$ & 0.48 & 0.50 & 53.40 & 8.23 & 13.86 \\
\hline \multicolumn{11}{|c|}{ Sandy calcareous soils } \\
\hline \multirow{5}{*}{$\begin{array}{c}\text { C-Sand } \\
\text { calcareous }\end{array}$} & $0--28$ & 7.70 & 11.64 & 80.66 & Loamy sand & 7.40 & 0.40 & 1.74 & 8.60 & 8.34 \\
\hline & $28--40$ & 25.32 & 14.57 & 60.11 & $\begin{array}{l}\text { Sandy clay } \\
\text { loam }\end{array}$ & 14.88 & 0.15 & 1.88 & 8.32 & 17.21 \\
\hline & $40--80$ & 23.21 & 14.56 & 62.23 & $\begin{array}{c}\text { Sandy clay } \\
\text { loam }\end{array}$ & 11.28 & 0.15 & 2.63 & 8.28 & 15.28 \\
\hline & $80--100$ & 16.74 & 16.13 & 67.13 & Sandy loam & 10.08 & 0.10 & 2.06 & 8.37 & 21.30 \\
\hline & $100-125$ & 22.40 & 9.65 & 67.95 & $\begin{array}{c}\text { Sandy clay } \\
\text { loam }\end{array}$ & 9.44 & 0.10 & 2.15 & 8.36 & 15.25 \\
\hline \multicolumn{11}{|c|}{ Alluvial calcareous soils } \\
\hline \multirow{3}{*}{$\begin{array}{l}\text { D-alluvial } \\
\text { calcareous }\end{array}$} & $0--20$ & 33.04 & 20.90 & 46.06 & $\begin{array}{c}\text { Sandy clay } \\
\text { loam }\end{array}$ & 22.24 & 1.30 & 10.10 & 8.25 & 21.14 \\
\hline & $20--40$ & 35.30 & 19.80 & 45.90 & $\begin{array}{c}\text { Sandy clay } \\
\text { loam }\end{array}$ & 20.00 & 1.38 & 13.35 & 8.15 & 17.28 \\
\hline & $40--70$ & 32.29 & 13.32 & 54.39 & $\begin{array}{c}\text { Sandy clay } \\
\text { loam }\end{array}$ & 31.80 & 0.19 & 5.06 & 8.49 & 7.21 \\
\hline \multicolumn{11}{|c|}{ Calcareous soils } \\
\hline \multirow{4}{*}{$\begin{array}{c}\text { E- } \\
\text { calcareous }\end{array}$} & $0--20$ & 28.11 & 28.17 & 43.72 & $\begin{array}{l}\text { Sandy clay } \\
\text { loam }\end{array}$ & 30.10 & 0.21 & 2.46 & 8.21 & 13.00 \\
\hline & $20--50$ & 37.73 & 32.49 & 29.78 & Clay loam & 38.22 & 0.68 & 2.48 & 8.42 & 14.08 \\
\hline & $50--80$ & 33.46 & 21.89 & 44.65 & Clay loam & 44.13 & 0.29 & 2.08 & 8.50 & 12.32 \\
\hline & 80--110 & 35.68 & 23.24 & 41.08 & Clay loam & 48.15 & 0.29 & 2.36 & 8.56 & 8.80 \\
\hline
\end{tabular}


sand and the intermediate layer $(80-100 \mathrm{~cm})$ were sandy loam.The texture of the calcareous soils varied from sandy clay loam in the upper $(0-20 \mathrm{~cm})$ to clay loam in the subsurface layers up to $110 \mathrm{~cm}$ depth. This could be due to the physical characteristics of parent material developed under marine and lagoonal conditions and to the increasing in carbonate content.

Regarding the distribution and content of $\mathrm{CaCO}_{3}$, the fluvial soils recorded the lowest value of total carbonate content (an average of $4.1 \%$ ) whereas the calcareous soils recorded the highest value (an average of 30.1\%). The amounts of total carbonate content tend to decrease or increase with depth according to soil formation circumstances and land use.

Values of Electrical conductivity (EC) had wide range in Delta soils which varied from 2.32 to 84.8 $\mathrm{dS} / \mathrm{m}$ in surface layer for fluvial and uncultivated lacustrine soils. In fluvial soil, EC values tend to increase with depth, whereas in uncultivated lacustrine soils took another direction which decreased with soil depth. This may be due to the effect of sea water intrusion and upward movement of water table (ElShahawy, 1994). On the other hand, EC values of Delta fringes soils ranged between 1.74 and $10.1 \mathrm{dS} / \mathrm{m}$ (in the upper soil layer) and tend to slightly increase with depth in sandy calcareous soils. In alluvial calcareous soils, EC values increased in subsurface layer and decreased in the deepest layer. This may be due to increase of total carbonate content which led to form confined water table and encourage upward water movement and in the same time decrease water deep percolation.

Organic matter content ranged between 1.78 and $2.02 \%$ in Delta soils and from 0.21 to $1.3 \%$ in Delta fringes soils. The lowest values of O.M. in delta fringes soils may be related to the low rate of organic matter addition and high rate of decompsion as compared to Delta soils. The values of $\mathrm{pH}$, generally ranged between 7.95 and 8.6 for all soils under study.

Concerning, the cation exchange capacity (CEC), their values ranged from 40.6 to 33.66 (meq/100g soil) in Delta soils and from 8.34 to 21.14 (meq/100g soil) in Delta fringes soils. It seems that CEC values correlated mainly with clay content of soils.

\section{Total and available heavy metals in soils:}

\section{1- Delta soils:}

Table2 showed that the surface layers of Delta soil contained higher amounts of total and available heavy metals $(\mathrm{Cu}, \mathrm{Ni}, \mathrm{Cd}$ and $\mathrm{Pb})$ than the subsurface soil layers which decreased with depth. This may be due to the cycling through vegetation, atmospheric deposition and adsorption by the colloidal materials. The results were similar to those obtained by El-Sikhry (1985), Elsokkary (1994) and Abou El-khir (2003).

The contents of total $\mathrm{Cu}, \mathrm{Ni}, \mathrm{Cd}$ and $\mathrm{Pb}$ in Delta soils varied from 246.3 to $102.5,186.3$ to $100.0,9.85$ to 1.85 and 175.0 to $60.0 \mathrm{mg} / \mathrm{kg}$, respectively. Whereas, the DTPA extractable values of these metals were 11.8, $0.78,0.21$ and $0.37 \mathrm{ppm}$, respectively for the above mentioned metals, for fluvial soils and 11.4, 0.80, 0.023 and $0.22 \mathrm{ppm}$, respectively, for lacustrine soils. Generally, total values of these metals were higher than in the natural concentrations in soil which were $100 \mathrm{ppm}$ for $\mathrm{Cu}, \mathrm{Pb}$ or $\mathrm{Ni}$ and $5 \mathrm{ppm}$ for $\mathrm{Cd}$ (Tietjen, 1975). Data showed that, the average contents of metals varied from one metal to another and from one soil to another. Therefore, these metals can be arranged, according to their contents, in the order: $\mathrm{Cu}>\mathrm{Pb}>\mathrm{Ni}>\mathrm{Cd}$. With regard to soil types, lacustrine soils recorded the lowest amounts of heavy metals as compared with fluvial soils. These results agree with those of Elsokkary and Lăg, (1980), Rashad et al., (1995), Aboulroos et al., (1996), Meshref et al., (1998) and Abou El-Khir, (2003).

Regarding the relative percentage of available to their total metals content; data showed that, this is increased in lacustrine soil compared to fluvial soil for all studied metals. The mean values of this ratio were 6.13, 0.47, 0.63 and $0.34 \%$ for $\mathrm{Cu}, \mathrm{Ni}, \mathrm{Cd}$ and $\mathrm{Pb}$ respectively, in the fluvial soil and were $11.73,1.78$, 1.09 and $0.57 \%$, respectively in the lacustrine soils. This my be due to the high clay content in fluvial than lacustrine soils.

\section{2- Delta fringes soils:}

Table 3 showed that the average content of total $\mathrm{Cu}$, $\mathrm{Ni}, \mathrm{Cd}$ and $\mathrm{Pb}$ in soils varied from one metal to another and also from one soil to another. Therefore, these metals can be arranged according to their total contents in the order: $\mathrm{Cu}>\mathrm{Pb}>\mathrm{Ni}>\mathrm{Cd}$. With regard to soil types, the contents of total $\mathrm{Cu}, \mathrm{Ni}, \mathrm{Cd}$ and $\mathrm{Pb}$ in soils varied from 57.5 to $120.0,62.5$ to $95.0,2.3$ to 4.65 and 39.5 to $69.5 \mathrm{mg} / \mathrm{kg}$, respectively for the surface soil layers. This indicates that alluvial calcareous soils recorded the lowest amounts of heavy metals, whereas sandy calcareous soils recorded the highest ones. The amounts of available metals varied in a relatively narrow range and the average were 2.11, 0.16, 0.035 and 0.20 $\mathrm{mg} / \mathrm{kg}$ for $\mathrm{Cu}, \mathrm{Ni}, \mathrm{Cd}$ and $\mathrm{Pb}$, respectively. The values tend to increase with depth among soil profile except for total $\mathrm{Cu}$ in sandy calcareous soil which decreased in subsurface layer and increased markedly in the other layers.The mean values of total metals in Delta fringes soils were generally higher than in normal soils, while, the available contents were lower than in the normal soils (Tietjen, 1975). These results were similar to those obtained by Elsokkary and Lăg (1980) and Aboulroos et 
al. (1996). The percentage of available metal relative to the total were nearly similar, and varied, generally in a narrow range, from 1.1 to $8.93 \%, 0.05$ to $0.66 \%, 0.48$

\section{Table Average values of the amounts of total}

Table2. Avera
Delta soils to $2.84 \%$ and 0.26 to $1.38 \%$ for $\mathrm{Cu}, \mathrm{Ni}, \mathrm{Cd}$ and $\mathrm{Pb}$, respectively.

\begin{tabular}{|c|c|c|c|c|c|c|c|c|c|c|c|c|}
\hline \multirow{2}{*}{$\begin{array}{l}\text { Soil } \\
\text { depth } \\
(\mathrm{cm})\end{array}$} & \multicolumn{2}{|c|}{$\mathrm{Cu}$ (ppm) } & \multicolumn{4}{|c|}{$\mathrm{Ni}(\mathrm{ppm})$} & \multicolumn{2}{|c|}{ Cd(ppm) } & \multicolumn{4}{|c|}{$\mathrm{Pb}(\mathbf{p p m})$} \\
\hline & T. & A. & $\begin{array}{l}\mathrm{A} / \mathrm{T} \\
(\%) \\
\end{array}$ & $\mathbf{T}$. & A. & $\begin{array}{l}\mathrm{A} / \mathrm{T} \\
(\%) \\
\end{array}$ & T. & A. & $\begin{array}{l}\mathrm{A} / \mathrm{T} \\
(\%) \\
\end{array}$ & T. & A. & $\begin{array}{l}\mathrm{A} / \mathrm{T} \\
(\%) \\
\end{array}$ \\
\hline \multicolumn{13}{|c|}{ Fluvial soil } \\
\hline $0--30$ & 246.3 & 11.8 & 4.78 & 186.3 & 0.78 & 0.42 & 9.85 & 0.21 & 2.10 & 175.0 & 0.37 & 0.21 \\
\hline $30--60$ & 186.3 & 9.38 & 5.04 & 112.5 & 0.70 & 0.63 & 7.13 & 0.044 & 0.62 & 145.0 & 0.34 & 0.23 \\
\hline 60--90 & 125.0 & 8.84 & 7.07 & 100.0 & 0.58 & 0.58 & 6.5 & 0.022 & 0.34 & 117.5 & 0.35 & 0.30 \\
\hline $90-120$ & 118.8 & 8.77 & 7.38 & 93.8 & 0.39 & 0.41 & 5.0 & 0.004 & 0.08 & 56.3 & 0.32 & 0.57 \\
\hline $120-150$ & 115.0 & 7.32 & 6.36 & 107.5 & 0.32 & 0.29 & 2.88 & 0.001 & 0.03 & 73.8 & 0.28 & 0.38 \\
\hline \multicolumn{13}{|c|}{ Lacustrine soil } \\
\hline $0--30$ & 102.5 & 11.4 & 11.08 & 100.0 & 0.80 & 0.8 & 1.85 & 0.023 & 1.24 & 60.0 & 0.22 & 0.37 \\
\hline $30--70$ & 88.5 & 10.8 & 12.19 & 19.0 & 0.62 & 3.28 & 1.70 & 0.012 & 0.71 & 49.0 & 0.54 & 1.10 \\
\hline $70--80$ & 62.5 & 7.5 & 11.92 & 12.5 & 0.15 & 1.22 & 0.60 & 0.008 & 1.33 & 27.5 & 0.07 & 0.25 \\
\hline
\end{tabular}

T. $=$ Total A. = Available

Table3. Average values of the amounts of total and available $\mathrm{Cu}, \mathrm{Ni}, \mathrm{Cd}$ and $\mathrm{Pb}(\mathrm{mg} / \mathrm{kg})$ in Delta fringes soils

\begin{tabular}{|c|c|c|c|c|c|c|c|c|c|c|c|c|}
\hline $\begin{array}{l}\text { Soil } \\
\text { depth } \\
(\mathrm{cm})\end{array}$ & $\mathrm{Cu}(\mathrm{pp}$ & & & $\mathrm{Ni}\left(\mathrm{p}_{\mathbf{I}}\right.$ & & & $\mathbf{C d}(\mathrm{p}$ & & & $\mathrm{Pb}(\mathrm{p}$ & & \\
\hline & T. & A. & $\begin{array}{l}\mathbf{A} / \mathbf{T} \\
(\%)\end{array}$ & T. & A. & $\begin{array}{l}\mathrm{A} / \mathrm{T} \\
(\%)\end{array}$ & T. & A. & $\begin{array}{l}\mathrm{A} / \mathrm{T} \\
(\%)\end{array}$ & T. & A. & $\begin{array}{l}\mathrm{A} / \mathrm{T} \\
(\%)\end{array}$ \\
\hline \multicolumn{13}{|c|}{ Sandy calcareous soil } \\
\hline $0--28$ & 120.0 & 1.71 & 1.42 & 95.0 & 0.22 & 0.23 & 4.65 & 0.03 & 0.65 & 69.5 & 0.20 & 0.29 \\
\hline $28--40$ & 73.0 & 1.38 & 1.88 & 81.5 & 0.26 & 0.32 & 2.90 & 0.02 & 0.79 & 57.0 & 0.15 & 0.26 \\
\hline $40--80$ & 91.5 & 1.76 & 1.92 & 70.5 & 0.12 & 0.17 & 3.65 & 0.00 & 0.00 & 20.0 & 0.28 & 1.38 \\
\hline $80--100$ & 118.5 & 1.47 & 1.24 & 59.0 & 0.00 & 0.00 & 4.25 & 0.05 & 1.15 & 45.0 & 0.17 & 0.38 \\
\hline $100-125$ & 131.0 & 1.44 & 1.10 & 31.0 & 0.11 & 0.35 & 3.90 & 0.05 & 1.28 & 41.5 & 0.00 & 0.00 \\
\hline \multicolumn{13}{|c|}{ Alluvial calcareous soil } \\
\hline $0--20$ & 57.5 & 3.80 & 6.62 & 62.5 & 0.41 & 0.66 & 2.30 & 0.02 & 0.74 & 39.5 & 0.37 & 0.93 \\
\hline 20--40 & 36.5 & 3.16 & 8.66 & 58.5 & 0.10 & 0.17 & 1.65 & 0.01 & 0.48 & 39.5 & 0.18 & 0.46 \\
\hline $40--70$ & 30.0 & 4.68 & 8.93 & 63.5 & 0.19 & 0.30 & 1.80 & 0.03 & 1.56 & 34.0 & 0.10 & 0.31 \\
\hline \multicolumn{13}{|c|}{ Calcareous soils } \\
\hline $0--20$ & 92.0 & 2.17 & 2.36 & 73.5 & 0.20 & 0.28 & 3.90 & 0.10 & 2.62 & 69.0 & 0.47 & 0.68 \\
\hline $20--50$ & 82.5 & 1.00 & 1.21 & 70.5 & 0.19 & 0.27 & 2.50 & 0.07 & 2.84 & 54.5 & 0.28 & 0.51 \\
\hline $50--80$ & 64.5 & 1.72 & 2.67 & 71.5 & 0.09 & 0.12 & 2.00 & 0.03 & 1.30 & 47.0 & 0.20 & 0.43 \\
\hline $80--110$ & 55.5 & 1.05 & 1.90 & 58.5 & 0.03 & 0.05 & 1.60 & 0.01 & 0.81 & 12.5 & 0.03 & 0.26 \\
\hline
\end{tabular}




\section{Heavy metals relation with soil properties:}

Table (4) showed the correlations between total and available heavy metals and some soil properties. The values revealed that the metal content is mainly dependent on soil parent material, organic matter content and cation exchange capacity of soils.

Highly significant positive correlations were found between clay and silt \% and total and available heavy metals. Fine-textured soils retain more $\mathrm{Cu}$ than coarsetextured soils. Apart from the clay content, the nature of clay mineral in soil also governs the retention and desorption of $\mathrm{Cu}$ (Srivastava and Gupta, 1996). Heavytextured soils are richer in $\mathrm{Cd}$ than light-textured soils. The retention of $\mathrm{Cd}$ by montmorillonite clay is at least five times greater than in the case of kaolinite (Khadr, 1961 and Zachara et al., 1992). High charge density sites are supposed to hold metals more strongly than low charge density sites (Ziper et al., 1988).

Organic matter revealed positive correlation with total metals and available metals except available $\mathrm{Cu}$. Srivastava and Gupta, (1996) found that $\mathrm{Cu}$ strongly binds with both soluble and insoluble organic matter in soil and peat soils retain a substantially high amount of $\mathrm{Cu}(130-190 \mathrm{meq} / 100 \mathrm{~g})$.

There were highly significant correlations between CEC and either total or available metals.

Table 4. Correlations between total and available heavy metals and soil properties

\begin{tabular}{|c|c|c|c|c|c|c|c|c|c|}
\hline & & \multicolumn{2}{|c|}{$\mathbf{C u}$} & \multicolumn{2}{|r|}{$\mathbf{N i}$} & \multicolumn{2}{|c|}{ Cd } & \multicolumn{2}{|c|}{$\mathbf{P b}$} \\
\hline & & Total & Available & Total & Available & Total & Available & Total & Available \\
\hline \multirow[t]{2}{*}{$\mathbf{C u}$} & Total & 1.00 & & & & & & & \\
\hline & Available & +0.50 & 1.00 & & & & & & \\
\hline \multirow[t]{2}{*}{$\mathbf{N i}$} & Total & +0.72 & +0.40 & 1.00 & & & & & \\
\hline & Available & +0.56 & +0.88 & 0.53 & 1.00 & & & & \\
\hline \multirow[t]{2}{*}{ Cd } & Total & +0.91 & +0.36 & 0.78 & +0.46 & 1.00 & & & \\
\hline & Available & +0.66 & +0.17 & 0.59 & +0.31 & +0.66 & 1.00 & & \\
\hline \multirow[t]{2}{*}{$\mathbf{P b}$} & Total & +0.86 & +0.58 & 0.81 & +0.69 & +0.87 & +0.66 & 1.00 & \\
\hline & Available & +0.32 & +0.46 & 0.31 & +0.58 & +0.35 & +0.26 & +0.46 & 1.00 \\
\hline \multicolumn{2}{|c|}{ Clay (\%) } & +0.35 & +0.29 & 0.65 & +0.38 & +0.52 & +0.21 & +0.63 & +0.25 \\
\hline \multicolumn{2}{|c|}{ Silt (\%) } & +0.52 & +0.40 & +0.70 & +0.41 & +0.63 & +0.16 & +0.65 & +0.32 \\
\hline \multicolumn{2}{|c|}{ Sand $(\%)$} & -0.46 & -0.37 & -0.71 & -0.41 & -0.60 & -0.19 & -0.66 & -0.30 \\
\hline \multicolumn{2}{|c|}{$\mathrm{CaCO}_{3}(\%)$} & -0.69 & -0.45 & -0.33 & -0.38 & -0.53 & -0.12 & -0.44 & -0.29 \\
\hline \multicolumn{2}{|c|}{ O M (\%) } & +0.36 & -0.16 & +0.54 & +0.04 & +0.46 & +0.50 & +0.44 & +0.21 \\
\hline \multicolumn{2}{|c|}{$\mathrm{EC}(\mathrm{ds} / \mathrm{m})$} & -0.01 & -0.38 & +0.12 & -0.30 & +0.07 & -0.13 & -0.07 & -0.07 \\
\hline \multicolumn{2}{|c|}{ pH } & -0.03 & +0.17 & -0.16 & +0.11 & +0.01 & +0.12 & +0.06 & +0.01 \\
\hline \multicolumn{2}{|c|}{ CEC (meq/100g soil) } & +0.69 & +0.55 & +0.64 & +0.54 & +0.71 & +0.19 & +0.75 & +0.41 \\
\hline
\end{tabular}

On the other hand, negative correlations were found between calcium carbonate and total and available metals. Calcareous soils retain higher amounts of $\mathrm{Cu}$ than other soils because of their greater adsorption of $\mathrm{Cu}$ on $\mathrm{CaCO}_{3}$ particles. The adsorption of $\mathrm{Cu}$ by clays and organic matter also increases with the increase in soil pH (Srivastava and Gupta, 1996).

Generally, soils having high clay content, $\mathrm{CaCO}_{3}$ and cation exchange capacity (CEC) retained more $\mathrm{Ni}$ (Estan et al., 1987). Soil organic matter metal-complexes and soluble organic compounds can increase the solubility of $\mathrm{Ni}$ and consequently its availability in soils. Low $\mathrm{pH}$ increases the solubility of $\mathrm{Ni}$ (Uren 1992).

It has also been reported that retention of $\mathrm{Cd}$ increases with increasing soil $\mathrm{pH}$ and consequently, $\mathrm{Cd}$ availability in the soil decreases with $\mathrm{pH}$. High $\mathrm{pH}$ favours precipitation of added $\mathrm{Cd}$ as $\mathrm{CdCO}_{3}$ (Eriksson, 1990). Humic substances form strong complexes with Cd (Petruzzelli et al., 1977) and reduce its mobility to lower horizons. The solubilization of $\mathrm{Cd}$ by organic matter occurs in the $\mathrm{pH}$ range of 7-8.

The content and solubility of $\mathrm{Pb}$ in soils decreases with $\mathrm{pH}, \mathrm{CEC}$ and available phosphorous. Lead forms relatively insoluble and stable chelates with organic matter (Srivastava and Gupta, 1996). 


\section{Conclusion}

Heavy metal contents in the studied soils are affected mainly by the geochemical source or soil parent material. The effects of extensive use of agrochemicals, practices of mechanization and atmospheric deposition are generally of secondary importance. Many authors suggested that soils should be protected from excessive inputs of heavy metals by fixing maximum acceptable levels of these metals in soils, corresponding to the amounts which will not cause any risk for crop failure or water pollution and human health. Cautions should be alarmed to prevent the continuous accumulation of these metals, which may finally lead to the soil pollution at a toxic level. To reduce dependence on agricultural agrochemicals, to promote cultural practices and to introduce and implement proven biological and alternative control technologies by integrated pest management.

\section{RE FERENCES}

Abou El-Khir, A.M. (2003). Trace elements and their relations to some soil properties in Kafr El-Sheikh soils. J.Agric. Res. Tanta Univ., 29(2):354-370.

Aboulroos, S.A., Holah, Sh. Sh., and Badawy, S.H. (1996). Background levels of some heavy metals in soils and corn in Egypt. Egypt. J. Soil Sic. 36: 83-97.

Alloway, B.J. (1995). Heavy Metals In Soils. Blackie Academic Professional, an Imprint of Chapman and Hall, Estern Cleddens Road, UK.

Alloway, B.J. (1990). Heavy metals in soils. John Wiley $\&$ Sons, New York.

Christensen, T. H. (1984). Cadmium soil sorption at low concentrations: I. Effect of time, cadmium load, $\mathrm{pH}$ and calcium. Water Air Soil Pollut. 21:105-114.

Cottenie, A.; P.M. Verloo; L. Kiekens; G Velghe and R. Camerlynck (1982). Chemical Analysis of Plants and Soils. Lab. Anal. and Agrochem. State Univ., Gent. Belgium, 63.

Dai, J.; T. Becquer; J. H. Rouiller; G. Reversat; F. B. Reversat; P. Lavelle (2004). Influence of heavy metals on $\mathrm{C}$ and $\mathrm{N}$ mineralization and microbial biomass in $\mathrm{Zn}-, \mathrm{Pb}-, \mathrm{Cu}-$, and $\mathrm{Cd}$-contaminated soils. Applied Soil Ecology 25: 99-109.

El-Shahawy, M. I. (1194). Pedochemical studies on some Egyptian soils. Ph.D.Thesis. Fac. Of Agric. Tanta University, Egypt.

El-Sikhry, E.M. (1985). Chemical status and behavior of certain heavy metals in some Egyptian soils and their relation to plants. Ph.D. Thesis, Fac. Agric. Ain Shams Univ.., Egypt.
Elsokkary, I. H. (1994). Contamination of the western area of Nile Delta by $\mathrm{Cd}, \mathrm{Pb}$ and $\mathrm{Hg}$. In: Global prospective of $\mathrm{Pb}, \mathrm{Hg}$, and $\mathrm{Cd}$ Cycling in the Environment. I.C. Hutchinsen, G. Gordan and K. Meama. Eds. Wiley Eastern Ltd. Pub., pp.217-234.

Elsokkary, I. H. and Lăg, J. (1980). Status of some trace elements in Egyptian soils and wheat grains. Beiträge trop. Landwirtsch. Veterinärned. 18: 35-47.

Estan , M. T., Bolarin, M.C., Guillen, M.G., and Caro, M. (1987). Adsorption of nickel in calcareous soils. Application of the angmuir isotherm and its modifications. Agrochimica 31: 344-354.

Eriksson, J. E. (1990). Effect of nitrogen-containing fertilizers on solubility and plant uptake of cadmium. Water Air Soil Pollut. 49: 355-368.

Gerriste, R. G. and W. Van Driel (1984). The relationship between adsorption of trace metals, organic matter, and $\mathrm{pH}$ in temperate soils. J. Environ. Qual. 13: 197-204.

Harter, R. D. (1979). Adsorption of copper and lead by Ap and B2 horizons of several northeastern United States soils. Soil Sci. Soc. Am. J. 43: 679-683.

Khadr, M. (1961). Heavy residues of some Egyptian soils. Geol. en. Mijnb., 40: 11-25.

Korte, N. E., J. Skopp,W. H. Fuller, E. E. Niebla, and B. A. Alesii (1976). Trace element movement in soils: Influence of soil physical and chemical properties. Soil Sci. 122: 350-359.

Lindsay, W.L. and Norvell (1978). Development of DTPA soil test for zinc, iron, manganese and copper. Soil Sci. Soc. Am. J. 42:421-428.

McBride, M.B.; Tyler, L.D. and Hord, D.A. (1981). Cadmium adsorption by soils and uptake by plants as affected by soil chemical properties. Soil Sci. Soc. Amer. J.45, 739-744.

McLaren, R.G.; Williams, J.G. and Swift, R.S.(1983). Some observations of the description and distribution behavior of copper with soil components. J. Soil. Sci. 34,325-331.

Meshref, H.A.; Kh.H. El-Hamdi; A.A. Hagag and M.Y. El-Arquan (1998). Evaluation of micronutrients status in some soils of the northern coast of Nile Delta. J. Agric. Mansoura Univ., 23: 2815-2825.

Morsy, M. (1990). "Studies on pollution of some Egyptian soil by heavy metals". Ph.D.Thesis Fac. Of Agric. El-Minia Univ.

Omran, M.S.; M.H. Shalaby and M.I. Raslan (1996). Effect of soil pollution on the growth and active 
ingredient of some medicinal plants. Egypt J. Soil Sci. 36: 59-67.

Page, A.L. (1994). Methods of Soil Analysis. $2^{\text {nd }}$ Edition, ASA,Madison, Wisconsin, USA.

Petruzzelli ,G., Guidi, G,. and Lubrano, L. (1977). Cadmium occurrence in soil organic matter and its availability to wheat seedlings. Water Air Soil Pollut. 8: 393-399.

Rabie, F.; A. Fawzy,; A. Khader and W. Hussein (1996). Content of biogenic and nonbiogenic heavy metals in El-Saff soils as related to different polluted sources. Egypt J. Soil Sci. 36: 165-177.

Rabie, F.; A. El-Araby and M. El-Shazly (1989). Micronutrients status as related to soil constituents in some soil of eastern desert of Egypt. J. Soil Sci., 29 (3):331-343.

Rashad, I.F.; A.O. Abd El-Nabi, M.E. El-Hemely and M.A. Khalaf (1995). Background levels of heavy metals in the Nile Delta soils. Egypt. J. Soil Sci. 35, No.2. pp. 239-252.
Sparks, D.L. (1995). Environmental Soil Chemistry. Academic Press, Inc., USA.

Shahin, R.R; and S.H.I. Abd El-Tawab (1988). Soil contamination with heavy metals and salts product by activities at Helwan Egypt. Egypt. J. Soil Sci., 23 (4):407-419.

Snedecor, G.W. and Cochran, D.W. (1967). Statistical methods. $6^{\text {th }}$ ed. Oxford and IBH Pub. Co., Calcutta, India.

Srivastava P. C. and U. C. Gupta, (1996). Trace elements in crop production. Copyright Reserved, Science Publishers, Inc. USA Chapters, 8 and 9.

Tietjen, C. (1975). Principal problems of the use of city wastes for crop production and soil conservation. F.A.O. Soil Bulletin 27.

Uren, N.C. (1992). Forms, reactions and availability of nickel in soils. Adv. Agron. 48:141-203.

Wright, S. (1921). Correlation and causation. J. Agric. Res. 20: 557-585.

Zachara, J. M., Smith, S.C., Resch, C.T., and Cowan , C.E. (1992). Cadmium sorption to soil separates containing layer silicates and iron and aluminum oxides. Soil Sci. Soc. Amer. J. 56:1074-1084.

Ziper, C., Komarneni, S., and Baker, D. E. (1988). Specific cadmium sorption in relation to the crystal chemistry of clay minerals. Soil Sci. Soc. Amer. J. 56:1074-1084. 


\section{الملخص العربي}

\section{العوامل المؤثثة على الإستخلاص الكميائى لبعض العناصر الثقيلة من أنواع مختلفة من الأراضى فى مصر}

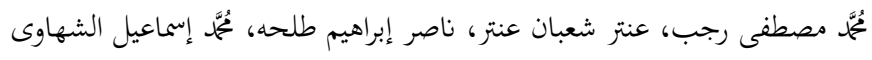

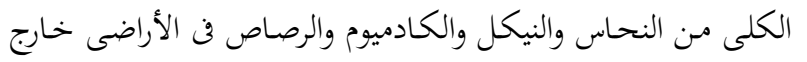

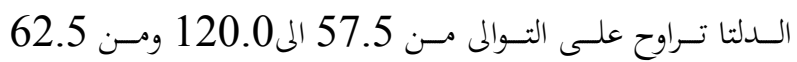
ومس2.3 الى الى 4.65 ومـن 39.5 الى 69.5 مليجـرام/كيلـوجرام

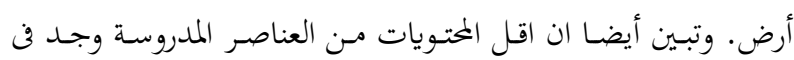

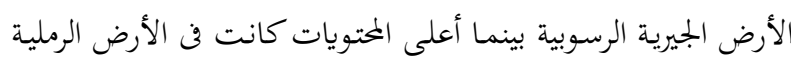

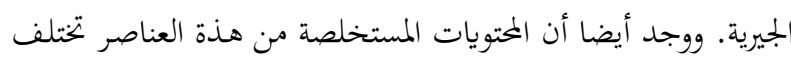

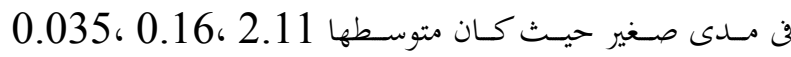

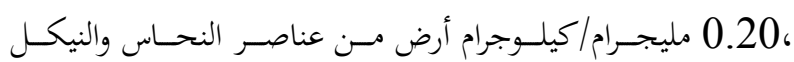
والكادميوم والرصاص على التوالى.

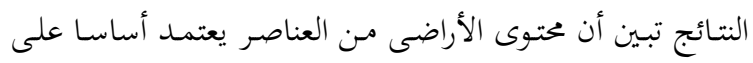
مادة الأصل والمادة العضوية والسعه التبادلية الكاتيونية. وتشير النتائج

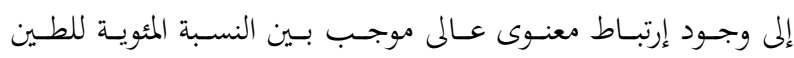

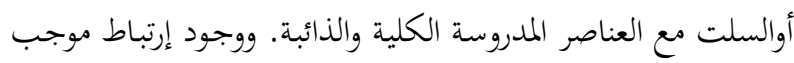

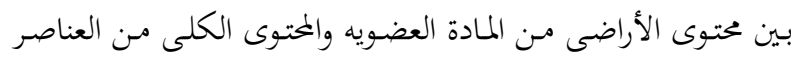

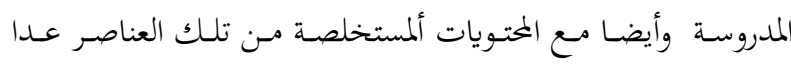
عنصر النحاس. وأيضا إرتبطت العناصر المدروسة الكلية و ألمستخلصة

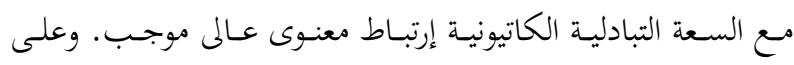
الجانب الأخر وجد إرتباط سالب بين محتويات الأراضى من كربونات

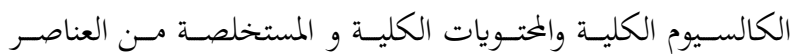

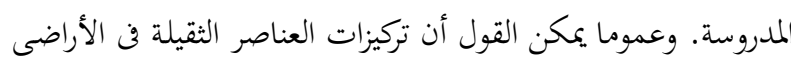

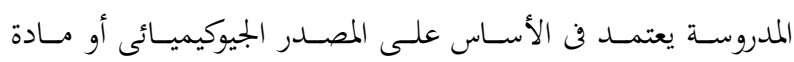

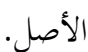

أجريت هذه الدراسة بهدف تقدير محتوى بعض الأراضى المصرية

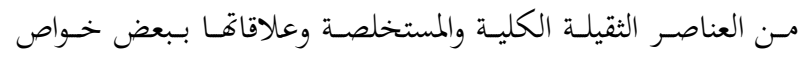

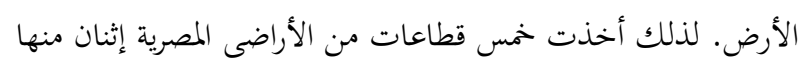

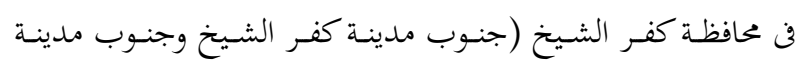

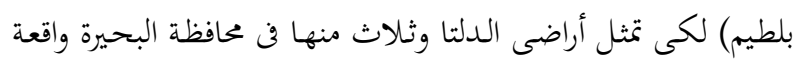
في مناطق حوش عيسى وأبو المطامير ومريوط لتمثل الأراضى خارج

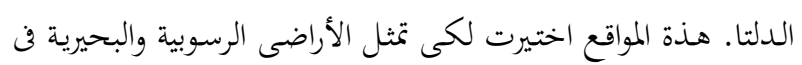

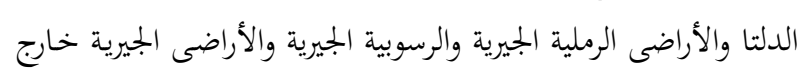
الدلتا. النتائج توضـح أن الطبقـات السطحية في أراضى الـدلتا تحتوى

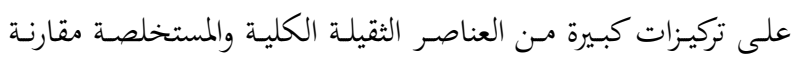
بالطبقات التحت سطحية وقلت تلك التركيزات مع العمق. تراوح

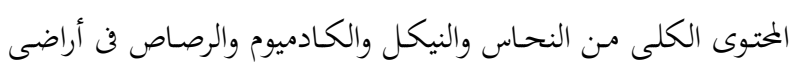

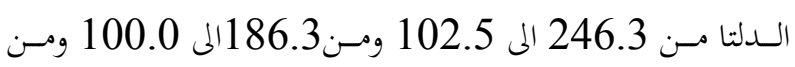

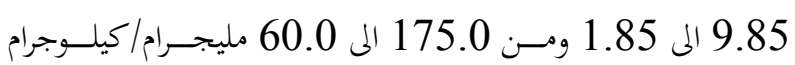
أرض على التوالى. وأيضا كانت القيم المستخلصة المماثلة لهذه العناصر

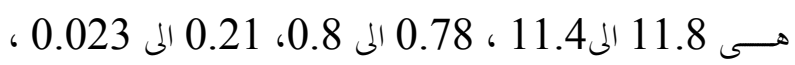
0.37 الى 0.22 مليجرام/كيلوجرام أرض على التوالى. وتشـير النتائج ان متوسط المحتوى الكلى مـن النحساس والنيكل

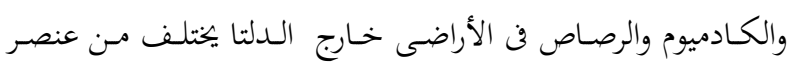

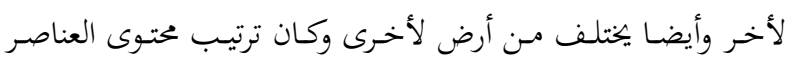

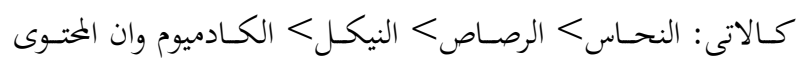

